\title{
Konferencja naukowa „Rodzina jako środowisko wychowawcze w czasach nowożytnych - koncepcje teoretyczne i praktyka"
}

Katedra Historii Wychowania Wyższej Szkoły Pedagogicznej w Bydgoszczy zorganizowała w dniach 3-4.04.1995 r. ogólnopolską sesję naukową poświęconą problematyce wychowania rodzinnego w czasach nowożytnych. Zjazd ten był kolejnym z etapów realizacji tematu związanego z poczynaniami badawczymi bydgoskiej Katedry, prowadzonymi od końca lat osiemdziesiatych.

Podejmując się koordynacji badań, ośrodek bydgoski liczy, że systematyczna współpraca będzie zmierzała do syntetyzowania ich wyników, a co za tym idzie opracowania chronologicznego i merytorycznego rozwoju teorii i praktyki wychowania rodzinnego w Polsce i Europie.

Konferencja spotkała się z szerokim zainteresowaniem i odzewem historyków, historyków wychowania oraz pedagogów reprezentujących wszystkie ośrodki naukowe kraju. Około 50 uczestników sesji było przedstawicielami 10 uniwersytetów, Instytutu Historii Nauki PAN, 4 wyższych szkół pedagogicznych, a także Uniwersytetu im. Mateja Bela w Bańskiej Bystrzycy (Słowacja).

Referowane w toku zjazdu badania były zarówno opisem stosunków panujących w rozpatrywanych rodzinach, jak również próbą ustalenia czynników determinujących sytuację społeczną i zmiany występujące $w$ bytowaniu rodzin $\mathrm{z}$ uwzględnieniem rozwarstwienia ich organizacji życia oraz spełniania funkcji wychowawczych. Rozpatrywane zjawiska były wyjaśniane w celu ustalenia moźliwych prawidłowości występujących w tej dziedzinie życia społecznego.

Zadaniem konferencji było rozpoznanie:

- zasobów źródłowych i sposobów ich wykorzystania w badaniach historyczno-pedagogicznych nad rodzina;

- idei, wartości, koncepcji i modeli wychowania rodzinnego;

- typów i przemian rodziny jako środowiska wychowawczego w czasach nowożytnych;

- stosunków rodziny i szkoły oraz problemów współdziałania tych środowisk wychowawczych w XX wieku.

Obrady otworzył J. M. Rektor WSP w Bydgoszczy prof. dr hab. Andrzej Tchorzewski, następnie głos zabral prezydent miasta Bydgoszczy mgr Stefan Pastuszewski, który w swym wystapieniu podkreślił wage i znaczenie badań nad rodzina oraz wskazał na niezastapione znaczenie społeczne, a także walory wychowawcze środowiska rodzinnego dziecka.

Sesjom plenarnym przewodniczyli kolejno profesorowie: Antoni Smołalski (Uniwersytet Opolski), Lech Mokrzecki (Uniwersytet Gdański), Franciszek Mincer (WSP Bydgoszcz). Debatami w sekcjach kierowali: prof. dr hab. Kalina Bartnicka (Zakład Dziejów Oświaty PAN) i dr hab. Witold Wojdylo (UMK Toruń).

Pierwszy dzień zjazdu rozpocząl się referatem prof. dr hab. Andrzeja Tchorzewskiego, w którym poruszył zagadnienie rodziny jako przedmiotu badań w naukach o wychowaniu. Następnie głos zabrał prof. dr hab. Juliusz Jundziłt, który dokonując analizy relacji zachodzących w rodzinie rzymskiej, określił wpływy społeczno - kulturowe na nią oddziaływujące i wskazał na trwałe wartości rzymskiego wychowania rodzinnego.

Kolejne wystapienia (zarówno pierwszego, jak i drugiego dnia) związane byly już bardzo ścišle $\mathrm{z}$ tematem i zakresem chronologicznym konferencji. Oparte zostały na różnorodnym materiale żródłowym. Najczęściej wykorzystywane były źródła literackie, w tym głównie pamiętmiki, beletrystyka, kalendarze, korespondencja prywatna, publicystyka prasowa, literatura psychologiczna i pedagogiczna oraz materiały dokumentowe. Releraty pedagogiczne były z kolei oparte na badaniach empirycznych.

Znakomita większość opracowań miała charakter szczegółowych analiz historycznych odnoszących się do dziejów narodowych. Wśród nich znajdowało się pięć dotyczących różnych aspektów praktyki i zapatrywań teoretycznych zwiąanych z wychowaniem rodzinnym w I Rzeczypospolitej. Zaliczyć do nich można prace: prof. dr hab. Lecha Mokrzeckiego Edukacja w rodzinach mieszczańskich w okresie I Rzeczypospolitej - na przykladzie Prus Królewskich; dr 
Doroty Żołąż Tradycje rodzinne w polskim wychowaniu szlacheckim - ХИ i XVI wiek; dr Romana Stępnia Rola rodziny w wychowaniu dzieci na podstawie poglqdow pedagogicznych ks. Antoniego Poplawskiego; Iwony Bakalarskiej Wplyw rodziny na wychowanie dzieci w swietle pogladów pedagogicznych Stanislawa Staszica i dr Adama Winiarza Rola $i$ znaczenie matki $w$ polskiej rodzinie magnackiej $i$ szlacheckiej w XVI-XIX wieku. Ciqglość $i$ zmiana.

Trzynaście referatów poświęconych było czasom zaborów, kiedy to - jak wskazywali autorzy - rodziny polskie stały się ostoją kultury narodowej i religii. Wszystkie akcentowały wartości patriotyczne ówczesnego wychowania rodzinnego. Doc. Krystyna Wróbel-Lipowa na przykładzie polskiej rodziny ziemiańskiej w XIX wieku, ukazała panujące w niej stosunki i priorytety wychowawcze; mgr Kazimierz Adamczyk przedstawil instrukcje generała Wladysława Zamoyskiego Do wychowania synów moich. O wpływie rodziny na kształtowanie postaw patriotycznych młodzieży w Galicji mówił referat dr Stefanii Walasek, zaś temat dotyczący pielęgnowania patriotyzmu w domach szlacheckich przed rokiem 1830 przybliżył zgromadzonym dr Andrzej Ladyżyński.

Problematyka rodzinna w beletrystyce polskiej była przedmiotem wystapienia prof. dr hab. Tadeusza Jałmużny, natomiast o wychowaniu w rodzinie na podstawie periodyku Kosciól i Szkola mówił prof. dr hab. Jan Hellwig. Dr Andrzej Denisiuk opierając się na relacjach pamiętnikarskich przedstawil dylematy wychowania w rodzinie na Pomorzu w drugiej polowie XIX i na początku XX stulecia.

Zagadnienie poruszające rolę kobiety i jej wpływ na wychowanie dziecka w Galicji omówila dr Aleksandra Bilewicz, zaś tytul referatu mgr Lidii Burzyńskiej brzmiał: Wychowanie w rodzinach polskich a postawy dzieci $i$ rodziców wobec kwestii jezyka polskiego $w$ dobie strajków szkolnych w latach 1906-1907 w Prusach Zachodnich. Dr Grażyna Kempa omawiając funkcje wychowawcze matki w rodzinie na Górnym Śląsku korzystała z czasopism kobiecych, dla dr Agnieszki Stopińskiej - Pająk źródłem w badaniach historyczno-pedagogicznych nad rodziną Śląską na przełomie XIX i XX wieku był kalendarz. Znaczenie pielgrzymek rodzin górnośląskich do miejsc kultu narodowego w latach 1869 - 1914 stanowiło temat przewodni wystąpienia mgr Mirosława Wójcika.

Pierwszym dekadom XX wieku - czasom II Rzeczypospolitej, przewagi ideologii narodowej i państwowej oraz wielkich grup spoleczno-zawodowych nad rodziną - poświęconych bylo dziewięc referatów. Ich autorzy rozpatrywali m.in. funkcjonowanie różnych typów rodzin w środowiskach lokalnych (prof. dr hab. Regina Renz, mgr Mirosław Piwowarczyk, mgr Beata Pituła), ich modele i zadania formulowane w ówczesnych programach ideowo-wychowawczych ruchu narodowego i ludowego (prof. dr hab. Danuta Koźmian, dr hab. Witold Wojdyło, dr Wiesław Jamrożek) oraz $w$ refleksji pedagogicznej okresu międzywojennego (dr dr Krzysztor Jakubiak i Leszek Albański oraz mgr Lidia Kaczmarek-Kielb).

Ostatnia grupa, do której należało osiem referatów dotyczyła różnych aspektów funkcjonowania rodziny jako śodowiska wychowawczego w rzeczywistosci społeczno-politycznej Polski i Słowacji po II wojnie światowej. Zależć można było wśród nich zarówno opracowanie historyczne przedstawiajqce zapatrywania na rolę społeczna i funkcje wychowawcze rodziny prezentowane przez Kościół katolicki i opozycyjne wobec władzy komunistycznej ugrupowania polityczne w latach 1945 - 1948 (dr Michał Strzelecki), analizę historyczno-pedagogiczną stosunków między rodziną i szkołą do 1989 r. (dr Andrzej W. Janke), jak i teksty stricte pedagogiczne, ukazujace wyniki badań empirycznych na temat wychowawczego $i$ edukacyjnego funkcjonowania rodzin polskich i słowackich oraz ich współdziałania ze szkoła (dr dr Zofia Brańka, Grażyna Sztanke, Juraj Satánek, Maria Gondovả, Libusa Gajdosowà, Pavol Bartlik).

Konferencję zakończylo posiedzenie plenarne, w toku którego przewodniczący sekcji podsumowali obrady i przebieg dyskusji w grupach. Istotne dopełnienie dwudniowej sesji stanowiły rozważania prof. dr hab. Antoniego Smołalskiego. Poświęcone one były zagadnieniu wykorzystania wiedzy historycznej w koniecznym procesie doskonalenia życia współczesnych rodzin i spelniania przez nie funkcji opiekuńczo-wychowawczych.

Ilona Blaszczyk 